\title{
Language Learning Strategy Use and English Proficiency of Iraqi Upper Secondary School Students
}

Qusay Mahdi Mutar*

University of Baghdad, Iraq

Corresponding Author: Qusay Mahdi Mutar, E-mail: Lm3qusay@perc.uobaghdad.edu.iq

\section{ARTICLE INFO}

Article history

Received: March 26, 2018

Accepted: June 04, 2018

Published: August 31, 2018

Volume: 9 Issue: 4

Advance access: July 2018

Conflicts of interest: None

Funding: None

\section{Key words:}

English Proficiency,

Gender,

Language-learning Strategies,

Sixth-Grade Preparatory Students,

Strategy Inventory For Language

Learning (SILL).

\begin{abstract}
To learn English language, there are some language-learning strategies, which learners need to be familiar with. Thus, the purpose of this study is to investigate the language learning strategies used among Iraqi sixth-grade preparatory students, and how could gender and proficiency level effect on using language-learning strategies. To analyze the collected data, SPSS software version 20 included Independent sample T-Test Besides, one-way ANOVA and Tukey HSD have been used. A total of 210 sixth-grade preparatory students were chosen randomly from four-different secondary schools for the academic year 2016-2017 at al-Karkh side of Baghdad city. The study sample consisted of (105 females and 105 males). The findings revealed that EFL learners have shown medium use of language learning strategies, besides, no statistically significant differences between male and female students in the frequency of using LLSs. the findings also showed Cognitive and memory strategies were the most frequent used categories comparing to the compensation strategies that scored the least frequent category. As for language proficiency, the result showed that students with high proficiency used all six categories of learning strategies more than medium and low-proficiency students.
\end{abstract}

\section{INTRODUCTION}

There is no doubt that English language nowadays is conceiving as number one among the world's languages. It has been termed as a global language for its wide usage in current business communication, navigation, science and above all that in scientific publication. Johansson and Jonsson (2006) stated that two thirds of all scientific publications are written in English language. Mastering English language gives an opportunity for learners to get a better job (Flanegin \& Rudd, 2000). However, learning English language as stated over time is not that easy task to be mastered for many learners. In respect of this, numerous studies have found that there is a noticeable discrepancy of acquiring English language as a foreign or second language among learners: this significant difference among learners has triggered the attention of specialists over the world. Since the sixties of last century, numbers of social, cognitive, affective, and metacognitive domains were identified as crucial domains that contribute to learning second language (brown, 2000). These domains have subsumed under the different types of language learning strategies such as memory, cognitive, compensation, metacognitive, effective, and social strategies.

Language learning strategies known as applicable steps chosen by learners to enhance their language learning pro- cess and make it more enjoyable, faster, self-directed, active, and consequently, transfer their knowledge to more advanced level (oxford, 1990). Boroujeni (2014) reported that two main objectives ascribed to use LLSs: they stimulate learners to apprehend and recognize the target language more efficiently, and the proper practicing of language learning strategies helps learner to enhance his autonomy in the process of learning without the assistance teacher. Rubin (1975) describes language-learning strategies as a set of useful techniques that employ to broaden learners acquired information; she also classified language-learning strategies into two types; these strategies that contribute to learning language directly and those that influence learning language indirectly. In a study of Oxford and Nyikos (1989) showed the positive correlation between learners' success in acquiring second language and language learning strategies use. O'Malley, Chamot, and Russo (1985) found that LLSs have an enormous influence as effective factors on learners' development process in getting a new language.

The disparity in learning language among learners could be attributed to a wide variety of potential variables might affect the use of language learning strategies such as gender, proficiency level, attitude, motivation, situation, anxiety, cognitive style, and self-confidence. Among these important 
variables, two variables will be addressed in this study: gender and learners' proficiency level and how they significantly affect the use LLSs. As one of the variables that have a profound impact on picking up learning strategies, Green \& Oxford (1995) reported that gender takes a substantial and vital role in language learning strategies use, they found that females tend to use more strategies than males do which is consistent with the result of Kato (2005) who examined EFL Japanese students. In his study, Tam (2013) investigated LLSs and its relationship to gender and learner proficiency level among university students. He found that males are less use of language learning strategies comparing to females who proved that they utilize LLSs more frequently and effectively in language learning process. Additionally, learners with high-proficiency level showed a high-score mean than those with low proficiency.

According to (Green \& Oxford, 1995; Oxford \& Burry-Stock, 1995) reported that using language-learning strategies is explicitly related to the level of language proficiency. Many scholars and researchers (e.g. Kevin, 2013; Sawako, 2009; Carol, 2003; Chen, 2002) have shown that learners with high-proficiency level use significantly a considerable number of language learning strategies over learning process than those with low-proficiency level. Some other studies (e.g. Abraham \& Vann, 1987; Chamot et al., 1988; Vandergrift, 1997) clearly revealed that low-proficiency learners are similar to high-proficiency learners are utilizing actively an abundant number of strategies, but they lack the knowledge of choosing the more efficient and appropriate strategies. The importance of doing this study emerged from the fact that language-learning strategies constitute significant practices through learning process that can not be overlooked by learners, Since they increase the skills of students' performance and academic achievement, which is controversial matter in Iraqi context. Regarding the context of Iraq, there have been too few research studies considered the use of LLSs among Iraqi young students. Accordingly, this study is attempt to investigate the language learning strategies used among Iraqi sixth-grade preparatory students, and how could gender and proficiency level influence the use of language-learning strategies. The result of this study expects to contribute theoretically and practically to the literature. It could be used as reference for the future studies that deal with acquiring second language, as well as, it will raise students' awareness, particularly Iraqi high school students, and teachers' awareness of the usefulness of LLSs used in language learning.

\section{Objectives of Study}

1) To identify the extent to which Iraqi sixth-grade preparatory students use language-learning strategies.

2) To compare male and female students in using language-learning strategies.

3) To identify the contribution of proficiency to language-learning strategies use among Iraqi sixth-grade preparatory students.

\section{Research Questions}

1) What strategies do Iraqi sixth-grade preparatory students use more frequently?

2) Is there any significant difference between male and female in using LLSs?

3) Are there significant differences between low, medium, and high-proficiency students in using LLSs?

\section{LITERATURE REVIEW}

\section{Language Learning Strategies}

As they defined by (O'malley \& Chamot, 1990) group of advantageous techniques that second language learners use to enhance their own knowledge and generate better language. Tarone (1983) defined Language learning strategies as "attempts to develop linguistic and sociolinguistic competence in the target language and to incorporate these into one's inter-language competence" (p.67). Oxford (1990) defined language-learning strategies as group of taken actions that help language learner in his learning process to make it more effective, easy, interesting, and more transferable to new situation. She classified language-learning strategies into classes, each class included set of categories. Over years, this classification considers as a comprehensive one. It is noteworthy that both cognitive learning theory (Anderson, 1983; Mclaughlin, 1987) and social cognitive theory (Vygotsky, 1978; Bandura, 1986) behind the derivation of second language learning strategies theories as well as they have offered the inspirations to utilize and develop learning strategies.

\section{Language Learning Strategies Classification}

This study used Oxford (1990) Language learning strategies inventory that classified into direct strategies that defined as these strategies that have direct effect at target language and necessitate mental processes; they include three strategies: memory, cognitive, and compensation strategy, as for indirect strategies, defined as these strategies that work on supporting and managing language indirectly. They consist of metacognitive, affective, and social strategy.

Table (1) below shows the classification of Oxford's (1990) Language learning strategies.

Oxford's (1990) classification of strategies

\begin{tabular}{|c|c|}
\hline Direct strategies & Indirect strategies \\
\hline $\begin{array}{l}\text { 1. Memory strategies } \\
\text { Help learners to memorize } \\
\text { and generate a new } \\
\text { information effectively. }\end{array}$ & $\begin{array}{l}\text { 1.Metacognitive strategies } \\
\text { Enable learners to organize and } \\
\text { evaluate their language learning. }\end{array}$ \\
\hline $\begin{array}{l}\text { 2.Cognitive strategies } \\
\text { Enable learners to } \\
\text { comprehend or create } \\
\text { language using mental } \\
\text { processes. }\end{array}$ & $\begin{array}{l}\text { 2.Affective strategies } \\
\text { Support learners to aware their } \\
\text { feelings, motivations and anxiety, } \\
\text { and then learners can adjust into } \\
\text { better ways. }\end{array}$ \\
\hline $\begin{array}{l}\text { 3.Compensation strategies } \\
\text { Allow learners to guess } \\
\text { or fill in the gaps caused } \\
\text { by insufficient language } \\
\text { proficiency. }\end{array}$ & $\begin{array}{l}\text { 3.Social strategies } \\
\text { Allow learners to interact with } \\
\text { and learn from other. }\end{array}$ \\
\hline
\end{tabular}




\section{Previous Studies}

Over the past few decades, numerous studies have been conducted to investigate language learning strategies use and how the use of these strategies could be influenced by some variables (e.g. gender, language proficiency, attitudes, individual traits, and some other variables). Ali \& Devrim (2014) conducted a study to evaluate the relationship between language learning strategies use and variables such as language proficiency, gender, and the age of students. A total of 186 elementary and intermediate level students whom were attending preparatory classes were collected randomly from university of Pamukkale. The researcher had employed strategy inventory for language learning that developed by Oxford (1990) as a basic instrument to round up the required data. The study findings revealed that the adult students showed a moderate use of SILL; males and females did not show significant differences upon using learning strategies. As for proficiency level, the use of language learning strategies significantly related to the level of students' language proficiency.

Kevin (2013) explored the contribution of language proficiency, gender, and the socioeconomic status of students to language learning strategy use. The researcher selected 50 new students from university of polytechnic in Hong Kong to provide this research with needed data. Kevin used two tools: SILL questionnaire version 7 that designed by oxford (1990) to measure LLSs used among students, and he also utilized the scores of English test to measure students' proficiency level. The results of the study revealed that females use language-learning strategies more significantly than male do. As a result, females acquire second language faster than that of males. Additionally, the findings indicated that there is a positive correlation between students' language proficiency and the use of compensation, social, and cognitive strategy.

Dongyue (2004) investigated the language learning strategies of Chinese university students who are learning English as a foreign language. Four-hundred-twenty-eight English major (male and female) students at Nanyang Institute of technology were served as the quantitative sample of the study. For data collection, the researcher employed strategy inventory of language learning questionnaire oxford (1990), and to determine students' proficiency level, students' examinations scores in listening and speaking were relied on. The research findings revealed that students with low-language proficiency use limited number of strategies; the case is different with those whom interest in high-proficiency level in English language. Furthermore, the research results showed that females use different strategies on their learning process than those that males use. Females proved over time, they use LLSs effectively and frequently in language learning process. Salahshour sharifi \& salahshour (2013) explored the language learning strategies use of 65 Iranian-high-school students based on students' language proficiency level and their gender. SILL scale was used to measure strategies use among students that developed by Oxford (1990), and to identify students' level of proficiency; English final scores was used for the study. The findings revealed that both males and females showed medium use of LLSs. However, language proficiency has shown a significant role in using strategies upon learning language. Rana, Sa'ad, and Nada (2010) carried out a study to investigate the effect of gender and language proficiency on (LLSs) among Iraqi university students. The study included a random sample of (83) second, third, and fourth stage Iraqi advanced EFL learners from college of education at university of Basra. As to collect research data, the author used Oxford's (1990) (SILL) questionnaire version 7.0 for (ESL/EFL). The findings have revealed that participants showed a medium use of language learning strategies. Metacognitive, social, and cognitive strategies are the most widely used among sample. Moreover, there is no significant difference between high and low-proficiency learners upon using (SILL) except on cognitive and compensation strategy, as for gender did not show a any statistical significant at the level of (0.05).

Based on the aforementioned literatures, many studies in different contexts have addressed the language learning strategies in relation to various variables. Nevertheless, to the best of author knowledge, none of these studies touches upon Iraqi sixth-grade preparatory students. Thus, this study attempts to investigate the contribution of gender and language proficiency level to using language-learning strategies among Iraqi sixth-grade preparatory students.

\section{METHODOLOGY}

\section{Participants}

A descriptive quantitative design was utilized in this research to collect and analyze data. As for study sample, the researcher has used stratified random sampling in this research, which is subtype of probability sampling. Stratified random sampling consists of homogeneous and non-overlapping strata (Bhattacherjee, 2012). The population of the current study included the sixth-grade preparatory students at al-Karkh side of Baghdad city. A total of 210 sixth-grade students were selected randomly to form study sample from four-different secondary schools for the academic year 2016-2017. The study sample consisted of (105 females and 105 males); they have been divided into three groups: low, medium, and high proficiency level. They were classified based on their scores in the final English exam in which students whom obtain above $90 \%$ are high proficiency, from $65-90 \%$ are medium, and less than $65 \%$ grouped as low proficiency. It is necessary to mention that all the 210 students have been learning English as a foreign language for eight years.

\section{Instrument}

As Oxford (1995) stated, numerous important studies have utilized SILL that took various versions over time. The current research administered the Strategy Inventory for Language Learning version 7.0 that adopted from Oxford (1990) as the basic instrument to investigate the employment of language learning strategies among Iraqi sixthgrade preparatory students. It is a self-scoring paper-pencil 
questionnaire that consist of six categories, each one has a number of items: (1) Memory strategy (eight items), (2) Cognitive strategy (11 items), (3) Compensation strategy (three items), (4) Metacognitive strategy (eight items), (5) Affective strategy (five items), and (6) Social strategy (five items). To lessen the misunderstanding of using the original version of SILL, It has been translated to the mother tongue of participants. The new-Arabic version was exposed to group of experts after some modification have been done; it observed as a reliable scale. The new-SILL Arabic version tabulated in 40 items with three-point Likert scale measuring the extent of using LLSs through learning process, it begins with (true of me) and ends with (never true of me). Oxford and Nyikos (1989) reported that in-depth reviews of literature were necessitated to put all these strategies together.

Table 1 shows the Alpha Cronbach's analysis for each category of SILL and the entire questionnaire that found to be 0.71 . The discrepancy of the reliability results depends on whether the survey administered in researcher own language or in the target language, but still accepted value even if the SILL's reliability decline little when taken in different language Oxford and Burry-stock (1995).

As for the second instrument, the scores of students' final exam in the English course for the academic year 2016/2017 have been used to measure English proficiency level, this exam represents a national-standardized exam that administers all over Iraq at the same time.

\section{Data Analysis}

To analyze the collected data, SPSS version 20 has been used. Descriptive statistics were implemented to answer question one that included the mean and stander deviation of all strategy categories used by subjects. Additionally, to determine if there is any significance between males and females on the level of using language-learning strategies, independent sample T-Test was used. Besides, one-way ANOVA and Tukey HSD were used to address the third research question, which is about the significance of proficiency level on language learning strategy use among Iraqi sixth-grade preparatory students. The statistical significance was measured at the level of 0.05 .

\section{RESULTS}

This section presents the analysis of data that were collected to answer the research questions.

\section{What Strategies do Iraqi Sixth-grade Preparatory Students use More Frequently?}

To compare the means of language learning strategies that were used frequently by study subjects, a descriptive analysis was done. As indicated in Table 2, there are two categories fell in the range of high use: Cognitive strategies followed by memory strategies, both of them have reached very high mean scores (3.692) and (3.312),
Table 1. SILL internal consistency reliability

\begin{tabular}{lcc}
\hline Strategy category & Alpha cronbach & Item \\
\hline Compensation strategy & 0.43 & 3 \\
Social strategy & 0.65 & 5 \\
Cognitive strategy & 0.79 & 11 \\
Affective strategy & 0.72 & 5 \\
Metacognitive strategy & 0.85 & 8 \\
Memory strategy & 0.83 & 8 \\
Total items & 0.71 & 40 \\
\hline
\end{tabular}

Table 2. Descriptive statistics of language learning strategies use

\begin{tabular}{lc}
\hline Strategy category & Mean \\
\hline Cognitive strategies & 3.692 \\
Memory strategies & 3.312 \\
Metacognitive strategies & 3.279 \\
Affective strategies & 3.249 \\
Social strategies & 3.028 \\
Compensation strategies & 2.001 \\
Total & 3.0935 \\
\hline
\end{tabular}

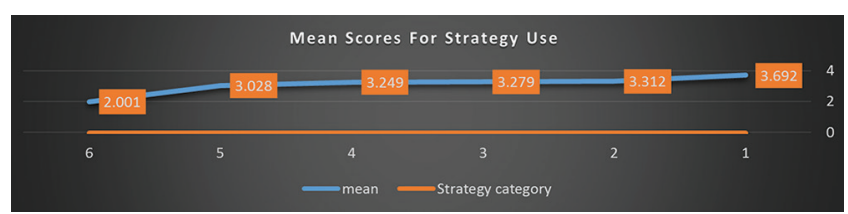

respectively. As for the lowest level of usage, compensation strategies reported to be the least used (2.001). Oxford (1990) defined mean score that register below $2.4(\mathrm{M} \leq 2.4)$ as a low use, and those fall between 2.5 and $3.4(2.5 \leq \mathrm{M} \leq 3.4)$ are considered to be medium use, as for mean score that register above $3.5(\mathrm{M} \geq 3.5)$ regard as a high use. Thus, the participants of study are categorized as medium strategy users since the overall mean score is (3.0935)

\section{Is there a Significant Difference between Male and Female in causing LLSs?}

To answer question two, independent sample T-test was used. As seen in Table 3, the mean scores reveal that male participants engaged in using strategies more frequent than female participants did. T-test results show statistically significant difference in the use of cognitive strategies $(\mathrm{P}=.015)$, metacognitive strategies $(\mathrm{P}=.005)$, and social strategies $(\mathrm{P}=.000)$ between males and females; the latter group employed these strategies less than the former did. On the other hand, Memory strategies $(\mathrm{P}=.491)$, Affective strategies $(\mathrm{P}=.568)$, and Compensation strategies $(\mathrm{P}=.875)$ did not show any difference between the two groups. However, the overall significance value $(0.325)$ is higher than $(0.05)$ which means no significant differences between male and female learners in using language-learning strategies. 
Table 3. The difference between male and female in using LLSs

\begin{tabular}{lccccccc}
\hline Strategy category & \multicolumn{2}{c}{ Male group } & \multicolumn{2}{c}{ Female group } & & T & Sig \\
\cline { 2 - 5 } & Mean & S.D & Mean & S.D & & & 0.015 \\
Cognitive strategies & 21.53 & 4.381 & 20.17 & 3.670 & 2.442 & 0.491 \\
Memory strategies & 15.41 & 2.545 & 15.19 & 2.104 & & 0.691 & 0.005 \\
Metacognitive strategies & 15.11 & 4.191 & 13.63 & 3.437 & 2.809 & 0.568 \\
Affective strategies & 10.14 & 2.359 & 9.96 & 2.218 & 0.573 & 0.163 & 0.00 \\
Social strategies & 10.12 & 2.364 & 8.56 & 2.004 & 5.157 & 0.875 \\
Compensation strategies & 5.10 & 1.285 & 5.13 & 1.345 & 0.157 & 0.325 \\
Total & 22.117 & 4.892 & 20.754 & 4.222 & 3.381 & \\
\hline
\end{tabular}

Table 4. One-way ANOVA results according to students' proficiency

\begin{tabular}{lccccc}
\hline Memory & Sum of squares & df & Mean squares & f & Sig. \\
\hline Between groups & 71.527 & 2 & 35.764 & 6.960 & 0.001 \\
Within groups & 1058.482 & 206 & 5.138 & \\
Total & 1130.010 & 208 & & \\
\hline
\end{tabular}

\begin{tabular}{llccc}
\hline \multicolumn{5}{c}{ Multiple comparison } \\
\hline (I) Proficiency & Tukey HSD & & \\
\hline high & (J) Proficiency & Mean differences (I-J) & Standard error & Sig. \\
& Middle & 0.499 & 0.385 & 0.389 \\
middle & Low & 1.413 & 0.385 & 0.001 \\
& High & -0.499 & 0.385 & 0.389 \\
low & Low & $-0.914^{*}$ & 0.383 & 0.047 \\
& High & $-1.413^{*}$ & 0.385 & 0.001 \\
\hline
\end{tabular}

\section{Are there Significant Differences between Low, Medium, and High-Proficiency Students in causing LLSs?}

To answer question three, one way ANOVA was used to examine if there is statistically significant difference among groups based on their proficiency level in using SILL. Further. The researcher used post hoc tests to identify which level is more significant when he finds statistical differences among groups through running ANOVA.

\section{Memory strategy}

To compare the using of strategies based on students' proficiency level in English language, one way ANOVA was used. As shown in Table 4, there are statistically significant differences among proficiency levels in term of using memory strategies $(\mathrm{F}=6.960, \mathrm{P}<.05)$. So as to find out which one of the proficiency levels is significantly different from other, post hoc tests have been used specifically tukey test to compare the means of students' levels. The results revealed that there are two significant values $(.001 ., 047<.05)$ high proficiency and middle proficiency respectively comparing to low proficiency level. For this end, we conclude that middle-proficiency students, as well as, high proficiency students use memory strategies more than low-proficiency students do.
Table 5. One way ANOVA results according to students' proficiency

\begin{tabular}{lccccc}
\hline compensation & $\begin{array}{c}\text { Sum of } \\
\text { squares }\end{array}$ & df & $\begin{array}{c}\text { Mean } \\
\text { squares }\end{array}$ & f & Sig. \\
\hline Between groups & 2.010 & 2 & 1.005 & 0.581 & 0.560 \\
Within groups & 358.014 & 207 & 1.730 & & \\
Total & 360.024 & 209 & & & \\
\hline
\end{tabular}

\section{Compensation}

As indicated in Table 5, the significance value is greater than $0.05(\mathrm{P}=.560)$. We conclude that there is no statistically significant difference between low, middle, and high proficiency levels in using compensation strategies.

\section{Affective}

Since the p. value has shown a higher score than 0.05 in ANOVA analysis as we see in Table 6. It can be concludes that using effective strategies did not have statistically significant differences among groups according to proficiency level.

\section{Cognitive}

Table 7 reveals significant differences among learners' groups in respect of using cognitive strategies; the sig- 
nificance score shows (0.000) which is less than (0.05). Thus, to identify which group among these three groups has a significant difference. It is necessary to run tukey HSD test. The results of multiple comparison analysis show significant differences of high proficiency and middle proficiency groups $(.000 ., 000<0.5)$ comparing to low proficiency group. In short, both of high and middle-proficiency groups use cognitive strategies in learning English language more than low-proficiency group do.

Table 6. One way ANOVA results according to students' proficiency

\begin{tabular}{lccccc}
\hline Effective & $\begin{array}{c}\text { Sum of } \\
\text { squares }\end{array}$ & df & $\begin{array}{c}\text { Mean } \\
\text { squares }\end{array}$ & f & Sig. \\
\hline $\begin{array}{l}\text { Between } \\
\text { groups }\end{array}$ & 21.629 & 2 & 10.814 & 2.025 & 0.135 \\
$\begin{array}{l}\text { Within } \\
\text { groups }\end{array}$ & 1105.686 & 207 & 5.341 & & \\
Total & 1127.314 & 209 & & & \\
\hline
\end{tabular}

\section{Metacognitive}

Table 8 shows the p-value of all groups is (.018); it is greater than (0.05) which means, there is a statistically significant difference among groups in using metacognitive strategies. So as to diagnose the multiple differences among the strategy users, post hoc tests were run. The multiple comparisons reveal middle-proficiency groups records a significant score $(0.015, \mathrm{P}<0.05)$ in comparison to high and low-proficiency groups (.611), (.150) respectively. In a brief, students with middle proficiency employ metacognitive strategies in learning language more than high and low-proficiency groups do.

\section{Social}

Since the p-value is $(.003<0.05)$ as the ANOVA results presented in Table 9, it can be concluded, there is a statistically significant difference between high, middle, and low-proficiency groups in employing language learning strategies. Consequently, post hoc tests were used to determine group that use strategies more significantly than others do. The re-

Table 7. One way ANOVA results according to students' proficiency

\begin{tabular}{|c|c|c|c|c|c|}
\hline cognitive & Sum of squares & df & Mean squares & $\mathbf{f}$ & Sig. \\
\hline $\begin{array}{l}\text { Between } \\
\text { groups }\end{array}$ & 466.552 & 2 & 233.276 & 15.948 & 0.000 \\
\hline $\begin{array}{l}\text { Within } \\
\text { groups }\end{array}$ & 3027.871 & 207 & 14.627 & & \\
\hline Total & 3494.424 & 209 & & & \\
\hline \multicolumn{6}{|c|}{ Multiple comparison } \\
\hline \multicolumn{6}{|c|}{ Tukey HSD } \\
\hline (I) Proficiency & (J) Proficiency & Me & ices (I-J) & Standard error & Sig. \\
\hline high & $\begin{array}{l}\text { Middle } \\
\text { Low }\end{array}$ & & & $\begin{array}{l}0.646 \\
0.646\end{array}$ & $\begin{array}{l}0.949 \\
0.000\end{array}$ \\
\hline middle & $\begin{array}{l}\text { High } \\
\text { Low }\end{array}$ & & & $\begin{array}{l}0.646 \\
0.646\end{array}$ & $\begin{array}{l}0.949 \\
0.000\end{array}$ \\
\hline low & $\begin{array}{l}\text { High } \\
\text { Middle }\end{array}$ & & & $\begin{array}{l}0.646 \\
0.646\end{array}$ & $\begin{array}{l}0.000 \\
0.000\end{array}$ \\
\hline
\end{tabular}

Table 8. One way ANOVA results according to students' proficiency

\begin{tabular}{|c|c|c|c|c|}
\hline Metacognitive & Sum of squares & Me: & $\mathbf{f}$ & Sig. \\
\hline Between groups & 121.229 & 2 & 4.114 & 0.018 \\
\hline Within groups & 3049.800 & 207 & & \\
\hline Total & 3171.029 & 209 & & \\
\hline \multicolumn{5}{|c|}{ Multiple comparison } \\
\hline \multicolumn{5}{|c|}{ Tukey HSD } \\
\hline (I) Proficiency & (J) Proficiency & Mean differences (I-J) & Standard error & Sig. \\
\hline high & $\begin{array}{l}\text { Middle } \\
\text { Low }\end{array}$ & $\begin{array}{l}0.614 \\
1.214\end{array}$ & $\begin{array}{l}0.649 \\
0.649\end{array}$ & $\begin{array}{l}0.611 \\
0.150\end{array}$ \\
\hline middle & $\begin{array}{l}\text { High } \\
\text { Low }\end{array}$ & $\begin{array}{c}0.614 \\
1.829 *\end{array}$ & $\begin{array}{l}0.649 \\
0.649\end{array}$ & $\begin{array}{l}0.611 \\
0.015\end{array}$ \\
\hline low & $\begin{array}{l}\text { High } \\
\text { Middle }\end{array}$ & $\begin{array}{c}1.214 \\
1.829^{*}\end{array}$ & $\begin{array}{l}0.649 \\
0.649\end{array}$ & $\begin{array}{l}0.150 \\
0.015\end{array}$ \\
\hline
\end{tabular}


Table 9. One way ANOVA results according to students' proficiency

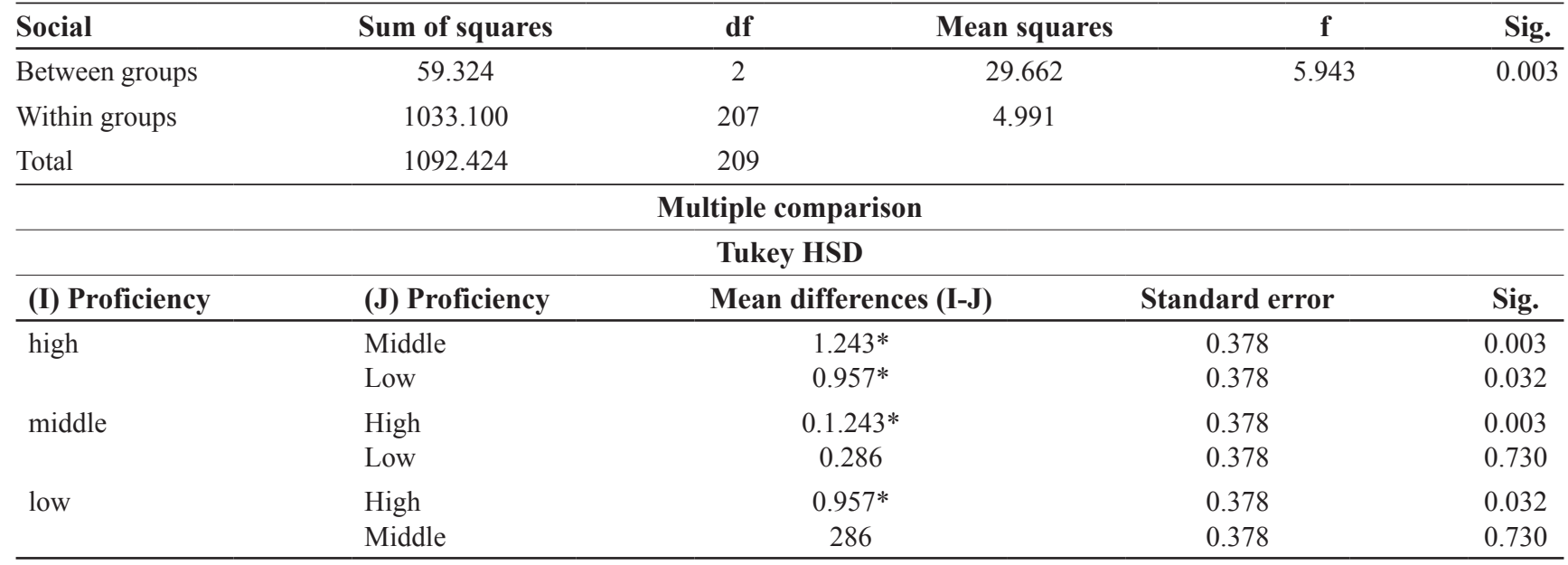

sults indicated high-proficiency group showed greater means $(1.243 ; .957, \mathrm{P}<0.05)$ than other groups in using social strategies in learning English language.

\section{DISCUSSION}

In general, the overall use mean of language-learning strategies has reported medium frequency. However, memory and cognitive strategies scored the highest means comparing to the other strategy categories. These findings inconsistent with the result of study carried out by (Abid et al, 2010) who investigated the using of language learning strategies among Iraqi university students. They found that both metacognitive and social strategies were more frequently used by learners among the six categories of LLSs, on the other hand, the mean score of using LLSs' by learners was similar to the current study at medium use. As for the less used strategy, compensation strategies is found to be the least category which comes to be in line with the result of Abid et al (2010) study. It is unlike to studies conduct by Liao (2000), Chen (2002), and yang (1992) reported that learners have used compensation strategies greater than other categories of learning strategies.

In line with current study, Abid et al (2010), Hoang (2013), Henno (2012), Griffiths (2003), Cao (2009), Yang (2010), Dodour \& Robbins (1996) found there is no statistically significant difference between males and females groups on overall language learning strategy use. This result contradicts with some previous studies that confirmed there is significant difference between males and females in using LLSs (Salahshour et al, 2013; Kevin, 2013; Lan \& Oxford, 2003; Taguchi, 2002; Ehrman \& Oxford, 1988). It is notable to mention that males revealed significant differences on using three categories (social, Cognitive, and metacognitive).

When we consider proficiency level, the findings revealed that the learners with low-language proficiency; the less frequently they use language learning strategies, and the learners with high-language proficiency; the more frequently they use language learning strategies. This result is compatible with results of studies conducted by (Kevin, 2013; Sawako, 2009;
Carol, 2003; Chen, 2002) have shown that learners with high-proficiency level use significantly-frequently a considerable number of language learning strategies over learning process than those with low-proficiency level. Two-strategy categories out of six have shown no significant differences between high, medium, and low-proficiency levels of learners namely affective and compensation strategies. It means, despite the various-proficiency levels, students did not show any discrepancy in using affective and compensation strategies; they are not used to exchange feelings, praise others when they present an interesting performance, and talk about issues that engage them. Moreover, the idea of using guessing, gestures, and hands movements is not common through their attempts speaking English. It is clear evidence of lacking the knowledge that boosts them to use all language learning strategies. Oxford and Ehrman (1995) stated the significance of using compensation and affective strategies, since they help EFL learners to overcome the barriers that encounter them when they come to interact with others.

\section{CONCLUSION}

This study was conducted to investigate the use of language learning strategies among Iraqi sixth-grade preparatory students and how could gender and proficiency level influence the use of language-learning strategies. The findings revealed that EFL learners have shown medium use of language learning strategies, there is no statistically significant difference between male and female students in the frequency of using LLSs. However, cognitive and memory strategies were the most frequent used categories comparing to compensation strategies that scored the least frequent category. As for language proficiency, the result showed that students with high proficiency used all six categories of learning strategies more than medium and low-proficiency students.

\section{PEDAGOGICAL IMPLICATION AND SUGGESTIONS}

Since the medium use of overall strategies, it is significant to raise students' awareness of the feasibility of using 
SILLs in learning foreign language. Teachers should expose these different types of strategies to students and illustrate that learning process could be more efficient and successful through employing the appropriate strategies. It is necessary to involve students in micro-teaching sessions that revolve around the benefit of using Language learning strategies. Chamot et al (1999) stated students who recognize the proper use of LLSs; they will be more motivated, efficient, and independent because LLSs reinforce students consciously to control the way they learn and examine their own progress. Despite interesting findings have been revealed, the researcher suggests conducting studies considering other factors such as (age, context, motivation, attitudes, and educational background) in relation with using language-learning strategies. Additionally, adopting mixed method approach in such studies since it gives in-depth understanding of research problem.

\section{REFERENCES}

Abid, R., \& Daghir, S. \& Ridha, N. (2010) Investigating the Relationship between Learner's Gender, Proficiency, and Language Learning Strategies: The Case of EFL Iraqi Learners. Adab Al-Basra journal, 53, 32-56

Abraham, R. G., \& Vann, R. J. (1987). Strategies of two language learners: A case study. In A. L. Wenden \& J. Rubin (Eds.), Learner strategies in language learning (pp.85-102). Englewood Cliffs, NJ: Prentice-Hall.

Erarslan, A., \& Höl, D. (2014). A study on language learning strategies of Turkish EFL learners at a state university. Journal of Second and Multiple Language AcquisitionJSMULA, 2(2), 1-10.

Anderson, J. R. (1983). The architecture of cognition. Cambridge: Harvard University Press.

Bandura, A. (1986). Social functions of thought and action: A social cognitive theory. Englewood Cliffs, NI: Prentice-Hall.

Bhattacherjee, A. (2012). Social Science Research: Principles, Methods, and Practices. Florida.

Boroujeni, Roohani, and Sharifi. 2014. Language Learning Strategy. RALs. Vol.5 (1) 44-55

Brown, H. D. (2000). Principles of second language learning and teaching ( $4^{\text {th }}$ ed.). Englewood Cliffs, N.J.: Prentice-Hall.McLaughlin, B. (1987). Theories of second language learning. London: Arnold.

Chamot, A. U., Küpper, L., \& Impink-Hernandez, M. (1988). A study of learning strate- gies in foreign language instruction: Findings of the longitudinal study. McLean, VA: Interstate Research Associates.

Chamot, A.U. \& EI-Dniary, P.B. (1999). Children's learning strategies in immersion classrooms. The Modern Language Journal, 83(3), 319-341.

Chen, I. J. (2002). Language learning strategies used by high and low English proficiency students in a technology college. Unpublished master's thesis, National Taiwan Normal University, Taipei, Taiwan.

Dongyue, L. (2004), EFL Proficiency, Gender and Language Learning Strategy Use Among a Group of Chinese Technological Institute English Majors. Arecls E-Journal, 1 (A5).
Dadour, E.S. \& Robbins, J., 1996: University-level studies using strategy instruction to improve speaking ability in Egypt and Japan. In R. Oxford (Ed.), Language Learning Strategies Around the World: Cross-cultural Perspectives (pp. 157-166). Manoa: University of Hawaii Press.

Flanegin, M., and Rudd, B. (2000). Integration Communication Skills and Business Education. Journal of Business Education. Retrieved from http://www.abe.villanova. edu./proceed2000.html

Green, J., \& Oxford, R.L. (1995). A closer look at learning strategies, L2 proficiency and gender. TESOL Quarterly, 29(2), 261-297.

Griffiths, C. (2003). Language learning strategy use and proficiency: The relationship between patterns of reported language learning strategy (LLS) use by speakers of other languages (SOL) and proficiency with implications for the teaching/learning situation (Doctoral dissertation, ResearchSpace@Auckland).

Johansson, I. and Jonsson, B. (2006). Effects of Teaching in English at Swedish Universities. Proceedings of the EDU-COM 2006 International Conference. Engagement and Empowerment: New Opportunities for Growth in Higher Education, Edith Cowan University, Perth Western Australia, 22-24 November 2006. Retrieved from http://ro.ecu.edu.au/ceducom/80 on $4^{\text {th }}$ September 2014 at $10 \mathrm{am}$

Kato, S. (2005). How language-learning strategies affect English proficiency in Japanese university students. Journal of the Faculty of Human Studies Bunkyo Gakuin University, 7(1), 239-262.

Kato, S. (2009). The Relationship of Language Learning Strategies and Personality on English Proficiency in Japanese University Students. The Journal of AsiaTEFL, 6(1), 141-162.

Kotzé, H. (2012). The relationship between the language learning strategy use and language proficiency of Vietnamese-speaking learners of English as a foreign language (Doctoral dissertation, Stellenbosch: Stellenbosch University).

Lan, R. \& Oxford, R. (2003). Language learning strategy profile of elementary school students in Taiwan. IRAL. 41, 339-379.

Liao, P.-S. (2002). Taiwanese Students' Beliefs about Translation and their Use of Translation as a Strategy to Learn English. (PhD thesis; Austin, USA: The University of Texas at Austin).

McLaughlin, B. (1987). Theories of second language learning. London: Arnold.

Nguyen, T. B. H. (2013). English learning strategies of Vietnamese tertiary students (Doctoral dissertation, University of Tasmania).

O’Malley, J. M., \& Chamot, A. U. (1990). Learning strategies in second language acquisition. Cambridge, UK: Cambridge University Press. 
Oxford, R. L. (1990). Language learning strategies: What every teacher should know. Boston, MA: Heinle \& Heinle Publishers.

Oxford, R. L., \& Burry-Stock, J. (1995). Assessment the use of language learning strategies worldwide with the ESL/EFL version of the strategy inventory for language learning (SILL). System, 23(1), 1-23.

Oxford, R., \& Nyikos, M. (1989). Variables affecting choice of language learning strategies by university students. Modern Language Journal, 73, 166-174.

Rubin, J. (1975). What the 'good learner' can teach us? TOESL Quarterly, 9(1), 41-51.

Salahshour, F., Sharifi, M., \& Salahshour, N. (2013). The relationship between language learning strategy use language proficiency level and learner gender. Procedia-Social and Behavioral Sciences, 70, 634-643

Tam, K. C. H. (2013). A study on language learning strategies (LLSs) of university students in Hong Kong. Taiwan Journal of Linguistics, 11(2), 1-42.
Tarone, E. (1983). Some Thoughts on the Notion of Communication Strateg. In C. Farerch, and G. Kasper (eds). Strategies in Interlanguage Communication. London: Longman, 61-74.

Vandergrift, L. (1997). The comprehension strategies of second language (French) listeners: A descriptive study. Foreign Language Annals, 30, 387-409.

Vandergrift, L. (1997). The Cinderella of communication strategies: Reception strategies in Interactive listening. The Modern Language Journal, 81, 494-505.

Vygotsky, L.S. (1978). Mind in Society. Cambridge, MA: Harvard University Press.

Yang, N. (1992). Second language learners' beliefs about language learning and their use of learning strategies: A study of college students of English in Taiwan. Unpublished doctoral dissertation, University of Texas, Austin.

Yang, M. (2010). Language learning strategies of English as a foreign language university students in Korea. Unpublished doctoral dissertation. Indiana State University. 